\title{
Utilization of Natural Iron Ore for Catalytic Reaction of Pyroligneous Acid Derived from Palm Kernel Shells
}

\section{Pemanfatan BijIh Besi sebagai Katalis pada Proses Reaksi Katalitik Pyroligneous acid yang BERASAL DaRI CANGKang KeLAPa SAWIT}

\author{
Muhammad Arifuddin Fitriady ${ }^{1, *}$, Dieni Mansur ${ }^{1}$, and Sabar Pangihutan Simanungkalit ${ }^{1}$ \\ ${ }^{1-3}$ Pusat Penelitian Kimia, Lembaga Ilmu Pengetahuan Indonesia, Kawasan Puspiptek Serpong,Tangerang \\ Selatan, Indonesia \\ "E-mail: dienilipi@gmail.com
}

\begin{tabular}{|c|c|}
\hline ART ICLE I NFO & Abstrak \\
\hline $\begin{array}{l}\text { Article history } \\
\text { Received date: } \\
3 \text { May } 2016 \\
\text { Received in revised form date: } \\
23 \text { June } 2016 \\
\text { Accepted date: } \\
1 \text { August } 2016 \\
\text { Available online date: } \\
30 \text { November } 2016\end{array}$ & $\begin{array}{l}\text { Kebutuhan energi dan penurunan bahan bakar fosil bersamaan dengan } \\
\text { munculnya kesadaran tentang kerusakan lingkungan menyiratkan bahwa } \\
\text { pasokan energi masa depan harus berasal dari sumber energi terbarukan. } \\
\text { Salah satu sumber energi terbarukan yang utama adalah biomasa. Pirolisa } \\
\text { adalah dekomposisi yang cepat dari material organik tanpa adanya gas } \\
\text { oksigen yang menghasilkan produk pyrolysis oil, gas, dan arang. Kandungan } \\
\text { air yang tinggi dan ketidakstabilannya; seperti perubahan viscositas dan } \\
\text { pemisahan fasa adalah masalah utama dari pyrolysis oil sebagai sumber } \\
\text { dari bahan kimia yang berguna. Pyrolysis oil terpisah menjadi fasa minyak } \\
\text { dan pyroligneous acid. Pyroligneous acid tersebut mengandung banyak } \\
\text { bahan kimia,oleh karenanya pyroligneous acid tidak dapat dibuang secara } \\
\text { langsung ke lingkungan karena akan mencemari lingkungan. Selanjutnya, } \\
\text { pyroligneous acid perlu diolah untuk mendapatkan bahan kimia yang bergu- } \\
\text { na. Reaksi katalitik dari pyroligneous acid yang didapat dari proses pirolisa } \\
\text { dari cangkang kelapa sawit, telah dilakukan dengan menggunakan katalis } \\
\text { bijih besi pada suhu } 350^{\circ} \text { C dengan W/F [W: massa tumpukan katalis (gram) } \\
\text { dan F : laju alir umpan (g. } \text { h }^{-1} \text { )] sebesar } 0,5 \text { h. Hasil analisis menunjukkan } \\
\text { bahwa bijih besi yang diberi pelakuan dengan kalsinasi pada suhu } 285{ }^{\circ} \mathrm{C} \\
\text { memiliki kemampuan yang lebih tinggi untuk reaksi ketonisasi dari asam } \\
\text { karboksilat dibandingkan dengan katalis lain. Walaupun begitu, baik kalsi- } \\
\text { nasi hingga suhu } 500{ }^{\circ} \text { C maupun perlakuan steam pada biji besi tidak dapat } \\
\text { menigkatkan aktivitas dari katalis untuk reaksi ketonisasi secara signifikan } \\
\text { meskipun luas permukaan BET dari katalis meningkat. }\end{array}$ \\
\hline
\end{tabular}

Kata kunci: Bijih besi, Reaksi katalitik, Pyroligneous acid, Pirolisa, Cangkang kelapa sawit.

Keywords:

Iron ores

Catalytic reaction

Pyroligneous acid

Pyrolysis

Palm kernel shells

\begin{abstract}
The energy demand and depletion of fossil fuels along with emerging consciousness about environmental degradation imply that the future energy supply has to come from renewable sources of energy. One of the major renewable energy sources is biomass. Pyrolysis is a rapid decomposition of organic materials in the absence of oxygen resulting in pyrolysis oil, gas, and charcoal products. High water contents and instabilities such as viscosity increase and phase separation are the main problems of pyrolysis oil as a source of useful chemicals. The pyrolysis oil is separated into the oil phase and the pyroligneous acid. The pyroligneous acid contains a lot of chemical substances, that prohibit removal to the environment as a waste due to environmental pollution. Furthermore, pyroligneous acid needs to be treated to obtain the useful chemical. In this study, catalytic reaction of the pyroligneous acid, derived from pyrolysis process of palm kernel shells, was carried out over natural iron ores catalyst at $350{ }^{\circ} \mathrm{C}$ with W/F [W: the amount of catalyst bed $(\mathrm{g})$ and $\mathrm{F}$ : the flow rate of feed $\left.\left(\mathrm{g} \mathrm{h}^{-1}\right)\right]$ of $0.5 \mathrm{~h}$. The analysis result showed that iron ores that treated by calcination at $285{ }^{\circ} \mathrm{C}$ had a higher ability for ketonization reaction of carboxylic acid compared to other catalysts. Even so, neither calcination up to $500{ }^{\circ} \mathrm{C}$ nor steam treatment of natural iron ores can significantly increase the activity of the catalyst for the ketonization reaction even though the BET surface area of the catalyst increased.
\end{abstract}




\section{INTRODUCTION}

Nowadays, the industrial and domestic energy needs of the society are fulfilled generally by the petroleum products. The demand for energy is increasing due to the rising growth of world population. The energy demand and depletion of fossil fuels along with emerging the awareness about environmental degradation imply that the future energy supply has to come from renewable sources of energy (Demirbas et al. 2001). One of the major renewable energy sources is biomass. Biomass is considered as a clean energy resource because it contains negligible amounts of nitrogen, sulfur, and ash compared to conventional fossil fuels, which results lower emissions of $\mathrm{SO}_{2}, \mathrm{NO}_{\mathrm{x}}$, and soot than the conventional fossil fuels (Q. Zhang et al. 2006; Börjesson 1996). In addition, $\mathrm{CO}_{2}$ released from biomass is overcomed by plants photosynthesis (Sembiring et al. 2015). Biomass can be used directly or indirectly by converting it into a gaseous or liquid fuel (LeValley et al. 2014).

Biomass can be converted to various forms of energy mainly by two types of processes: thermochemical, and biochemical (Dincer 2011). Biochemical processes decompose the biomass into biofuels by the action of the living organisms or their products. Biochemical processes produce a large amount of hydrogen in comparison with the other processes (Das et al. 2001). However, the efficiency of the biochemical process makes them less attractive for industries (Shweta et al. 2016).

Meanwhile, thermochemical conversion processes allowed biomass to break down into its constituents as bio-fuels, gasses, and chemicals by applying heat and pressure. Combustion, gasification, pyrolysis, and liquefaction are the four different types of thermochemical processes. Combustion can be defined as a complete oxidation of the fuel. The hot gasses coming from the combustion can be used for direct heating purposes. A solid fuel combustion process will always begin with drying and pyrolysis/gasification (Sjaak van et al. 2008).

The gasification is a thermochemical conversion process in which biomass is heated at high temperatures and produces combustible gasses. Air, steam, or oxygen can be used as a gasification agent to increase energy value (Kalinci et al 2009). The syngas produced is a gas mixture of carbon monoxide $(\mathrm{CO})$, hydrogen $\left(\mathrm{H}_{2}\right)$, methane $\left(\mathrm{CH}_{4}\right)$, carbon dioxide $\left(\mathrm{CO}_{2}\right)$, and hydrocarbons. However, undesirable gasses such as hydrosulphuric $\left(\mathrm{H}_{2} \mathrm{~S}\right)$ and hydrochloric acid $(\mathrm{HCl})$, or inert gasses such as nitrogen $\left(\mathrm{N}_{2}\right)$, can also be present in the syngas. (Molino et al. 2016).

Hydrothermal liquefaction can be determined as a conversion of biomass into liquid fuels by processing in a pressurized water environment to break down the solid biopolymeric structure to liquid components. Hydrothermal liquefaction was usually conducted in range temperature from $247{ }^{\circ} \mathrm{C}$ to $374{ }^{\circ} \mathrm{C}$. This process aimed to remove oxygen in order to make the product has higher energy density than raw material (Elliott et al. 2015).

Pyrolysis is a rapid decomposition of organic materials in the absence of oxygen which results in the production of liquid, gaseous and charcoal products. It is a promising thermal approach that can be used to convert biomass into energy in the forms of pyrolysis oil, solid charcoal, and syngas composed of $\mathrm{H}_{2}, \mathrm{CO}, \mathrm{CO}_{2}$, and hydrocarbon gasses. The drastic reduction of solid residue volume is the important advantage of pyrolysis compared to other energy conversion process (Sembiring et al. 2015). High water contents and instabilities such as viscosity increase and phase separation were the main problems of pyrolysis oil as a source of useful 
chemicals. Pyrolysis oil was separated into the oil phase and pyroligneous acid (Mansur et al. 2014; Bridgwater 2011).

The oil phase product, after some treatment, can be used as a fuel blend oil. However, the pyroligneous acid contains a lot of chemical substances, which causes it cannot be discarded to the environment as a waste due to environmental pollution. Furthermore pyroligneous acid needs to be treated to obtain the useful chemical (Mansur et al. 2013).

There are many previous studies about the treatment of pyroligneous acid such as its antioxidant capability from the walnut shell (Wei et al. 2010), mangrove plant (Loo et al. 2007), and pineapple (Mathew et al. 2015). All of the pyroligneous acids can be used as an alternative natural antioxidant. Sumanatrakul et al. (2015) reported that pyroligneous acid derived from $A s$ per Backer bamboo was capable of being used as an alternative antifungal and coagulating agent in a rubber sheet production process. Moreover, Möbius et al. (2012) studied about the usage of supercritical water gasification (SCWG) in gasification of pyroligneous acid which consists mainly of formic acid, glycolaldehyde, glycolic acid, and phenol. Temperature, residence time, TOC-concentration of feed, and usage of potassium carbonate as the catalyst were the variable of the study. It is reported that a higher gasification efficiency was achieved at high-temperature process condition and moderate residence times using low TOC-concentration of feed with the addition of potassium carbonate as catalyst (Möbius et al. 2012).

There are also many previous studies about iron oxide which used as a catalyst either to decompose plastic or upgrade bio oil. Zhang et al. (2014) reported that the $\mathrm{Fe}(\mathrm{III}) / \mathrm{CaO}$ catalyst can reduce the number of oxygenated compounds in the upgrading process of biomass fast pyrolysis vapor. The catalyst has the ability to produce light phenols from heavy phenols without any methoxyl group and unsaturated $\mathrm{C}-\mathrm{C}$ bonds on the side chain. Furthermore, the catalyst greatly decreased the yield of aldehydes and ketones and also completely eliminated the acids while significantly increase the yield of furans, light and aromatic hydrocarbons. It is reported that the zirconia-supporting iron oxide catalysts were capable of converting hydrocarbons contained in the product of hydrothermally liquefied sewage sludge to a mixture containing primarily acetone without any carbonaceous residue (Fumoto et al. 2006). The process was conducted at one atmospheric pressure and superheating steam atmosphere. Our previous study reported that the utilization of $\mathrm{ZrO}_{2}-\mathrm{FeO}_{\mathrm{X}}$ catalyst in the catalytic reaction can convert hydroxyacetone and carboxylic acids (acetic and propionic acids) contained in the pyroligneous acid into aliphatic ketones (acetone and 2-butanone) via ketonization reaction (Mansur et al. 2013).

In this study, we try to utilize natural iron ore to enhance its usability as a catalyst to replace zirconia-supporting iron oxide catalyst. Natural iron ore was treated to a potential catalyst and its activities was tested in catalytic reaction of the pyroligneous acid.

\section{MATERIALS AND METHODS \\ Materials}

ThePalmKernel Shells(PKS) were obtained from a palm oil mills of PTPN-IV located in Tombatu (North Sumatera-Indonesia). The shells were reduced in size using a size reducer (crusher 5HP) operating at 2800 rpm $\min ^{-1}$, dried in an oven at $100{ }^{\circ} \mathrm{C}$ overnight and then sieved to obtain chips between 0.84 and $4 \mathrm{~mm}$ in length. The cellulose, hemicellulose, lignin, ash, and 
moisture were analyzed using NREL methods and found to be $21.17,16.13$, $45.06,1.87$, and $15.77 \mathrm{wt} \%$ respectively (Hyman et al. 2008; Sluiter et al. 2008; Sluiter et al. 2008; Sluiter and Sluiter 2008). Moreover, the $\mathrm{C}, \mathrm{H}, \mathrm{N}$, and $\mathrm{O}$ content were analyzed using CHN 628 (Leco Corporation) and found to be 48.6, 6.29, 0.48 , and $44.63 \mathrm{wt} \%$ respectively. This carbon content value was used as the basis for calculation of the total carbon yield of products after the pyrolysis process.

\section{Thermal Gravimetric Analysis of Iron Ore}

Iron ore was weighed about 11-12 mg into a crucible and placed in sampling chamber. The sample was heated from $50-600$ ${ }^{\circ} \mathrm{C}$ with the heating rate of $10{ }^{\circ} \mathrm{C} \mathrm{min}^{-1}$ in nitrogen condition. The nitrogen gas flow rate was $50 \mathrm{ml} \mathrm{min}^{-1}$ as the carrier gas. At $600{ }^{\circ} \mathrm{C}$ the temperature was held for 5 min (isothermic) and then the heating was continued up to $950{ }^{\circ} \mathrm{C}$ in oxygen condition under the same flow rate and heating rate with nitrogen gas. The analysis was carried out using Netzsch TG 209 F3 Tarsus.

\section{XRD, SEM, and EDX Analysis of Iron Ore}

X-Ray analysis of iron ore was carried out in Research Centre for Physics, Indonesian Institute of Sciences using X-ray diffractometer, SmartLab, Rigaku. The microstructure of iron ore was analyzed by Scanning Electron Microscopy (SEM) type SU3500, Hitachi and point analysis was conducted by EDX X-max, Horiba that also located in the Research Centre of Physics.

\section{Pretreatment of Natural Iron Ore for Catalyst}

The natural iron ores were obtained from Lampung, Indonesia and treated in order to be able to used as a catalyst, the iron ores were treated in several ways to increase surface area. The treatments of iron ores were as follows:

1. Natural iron ore was crushed using porcelain mortar crusher then sieved to obtain $300-850 \mu \mathrm{m}$ of grains catalyst. This catalyst was used as the base catalyst to make other treated catalysts.

2. The grains catalyst were calcined at $285^{\circ} \mathrm{C}$ under heating and cooling rate of $10^{\circ} \mathrm{C} \mathrm{min}^{-1}$ and holding time of two hours.

3. The grains catalyst were calcined at $500{ }^{\circ} \mathrm{C}$ under heating and cooling rate of $2{ }^{\circ} \mathrm{C} \mathrm{min}{ }^{-1}$ and holding time of two hours.

4. The grains catalyst were treated by steam at $500{ }^{\circ} \mathrm{C}$ for an hour and then dried using drying oven at $120{ }^{\circ} \mathrm{C}$ overnight.

5. The grains catalyst were treated as the same as treatment no. 4 , and continued by calcination at $500{ }^{\circ} \mathrm{C}$ for two hours.

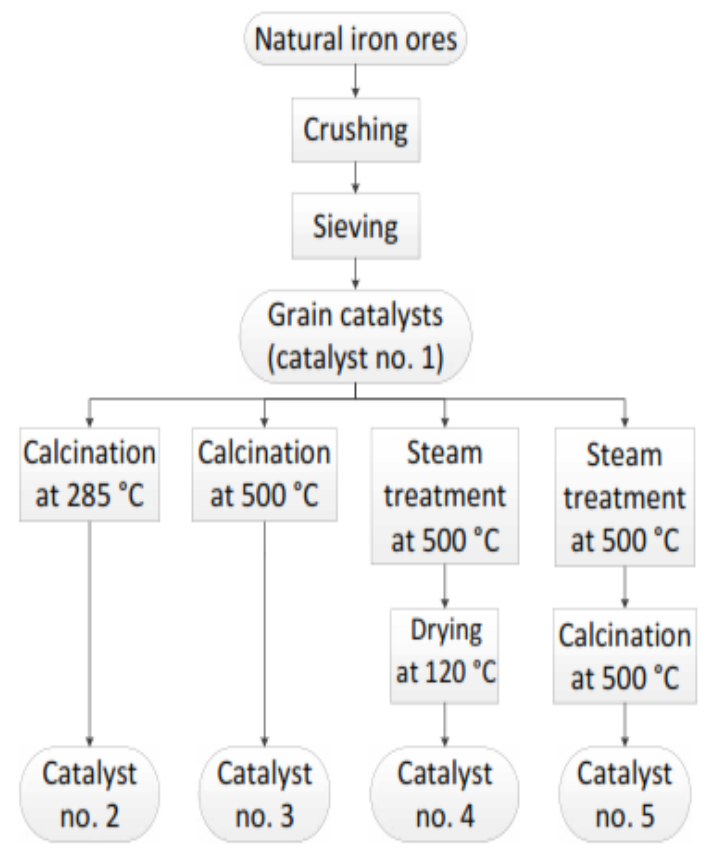

Figure 1. Natural iron ore treatment for the catalyst 
According to the natural iron ores treatment, there were five types of catalyst that used in this study. Simply, the catalyst and their symbols for pyroligneous acid catalytic reaction can be seen in Figure 1.

Calcination of natural iron ores was carried out in a high-temperature furnace (Thermolyne 46200). Moreover, the steam treatment was conducted in a fixed bed stainless steel reactor. The grains catalyst were placed in the reactor and heated up to $500{ }^{\circ} \mathrm{C}$. The dosing pump was switched on to supply water with the flows rate of 10 $\mathrm{ml} \mathrm{min}{ }^{-1}$. The water flow into the reactor and gradually becomes steam as the temperature increased. After contacting with catalyst, steam was discharged from the bottom of the reactor into the cold water trap. The process was maintained for an hour. A schematic diagram of the apparatus is shown in Figure 2.

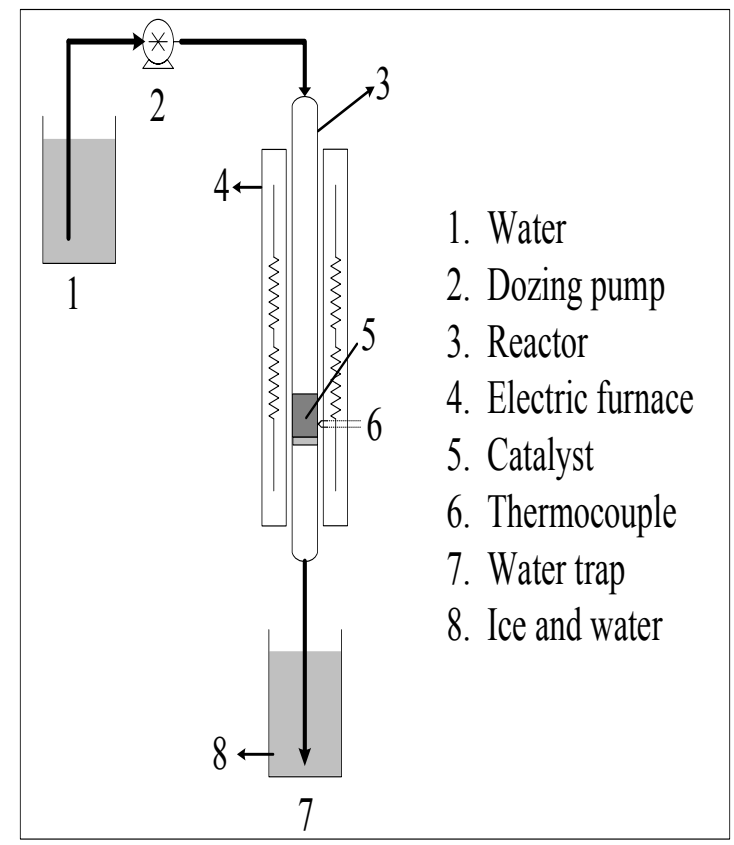

Figure 2. A schematic diagram of the apparatus for steam treatment of natural iron ore.

\section{Pyrolysis Process}

The pyrolysis experiments were carried out in a fixed-bed stainless steel flow reactor. The length and inner diameter of the pyroly- zer were $59.69 \mathrm{~cm}$ and $2.54 \mathrm{~cm}$, respectively. About $20 \mathrm{~g}$ of PKS chips were placed in the pyrolyzer. Nitrogen as a sweeping gas was passed through the pyrolyzer to remove air/oxygen. The nitrogen flow rate was set to $20 \mathrm{~cm}^{3} \mathrm{~min}^{-1}$. The process was maintained at temperature $550{ }^{\circ} \mathrm{C}$ for 50 min. The temperature was measured using a thermocouple located just below the bed. Three stages of the condenser $\left(0{ }^{\circ} \mathrm{C}\right)$ were installed to capture the vapor/liquid product, and non-condensable gasses were trapped in the water trap before it was released to the environment. A schematic diagram of the pyrolysis apparatus is given in Figure 3.

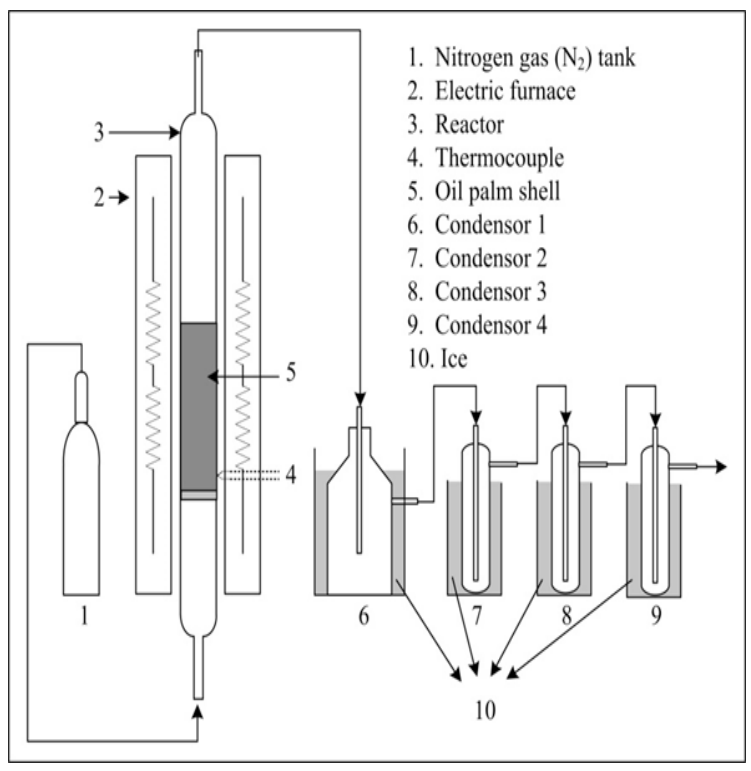

Figure 3. A schematic diagram of the pyrolysis apparatus

The heat of the pyrolyzer was terminated when the desired reaction time was reached, and the system was allowed to cool to room temperature. The pyrolyzer, and all condenser, including all of the connections tubes, were carefully removed from the system and weighed. Char remained on the bed after pyrolysis. Pyrolysis oil obtained in condenser then to be united in one condenser and let settled. The 
pyroligneous acid was removed from oil phase using a pipette and used as feedstock in the catalytic reaction.

\section{Catalytic Reaction of Pyroligneous Acid}

The catalytic reaction of pyroligneous acid over the iron ore catalyst was carried out in a fixed bed stainless steel flow reactor for two hours under atmospheric conditions at $350^{\circ} \mathrm{C}$. Two concentrations of pyroligneous acid: were produced, and $50 \%$ diluted in distilled water, hereafter called as $100 \%$ feed and $50 \%$ feed of pyroligneous acid respectively, were fed into the reactor as the variable process. Nitrogen gas $\left(15 \mathrm{~cm}^{3}\right.$ $\mathrm{min}^{-1}$ ) used as the carrier gas. W/F [W: Amount of catalyst bed (g) and F: Flow rate of feed $\left(\mathrm{g} \mathrm{h}^{-1}\right)$ ] was $0,5 \mathrm{~h}$. A schematic diagram of the apparatus for the catalytic reaction is shown in Figure 4.

After the catalytic reaction, gas and liquid products were collected in a gas pack and a condenser $\left(0^{\circ} \mathrm{C}\right)$ respectively.

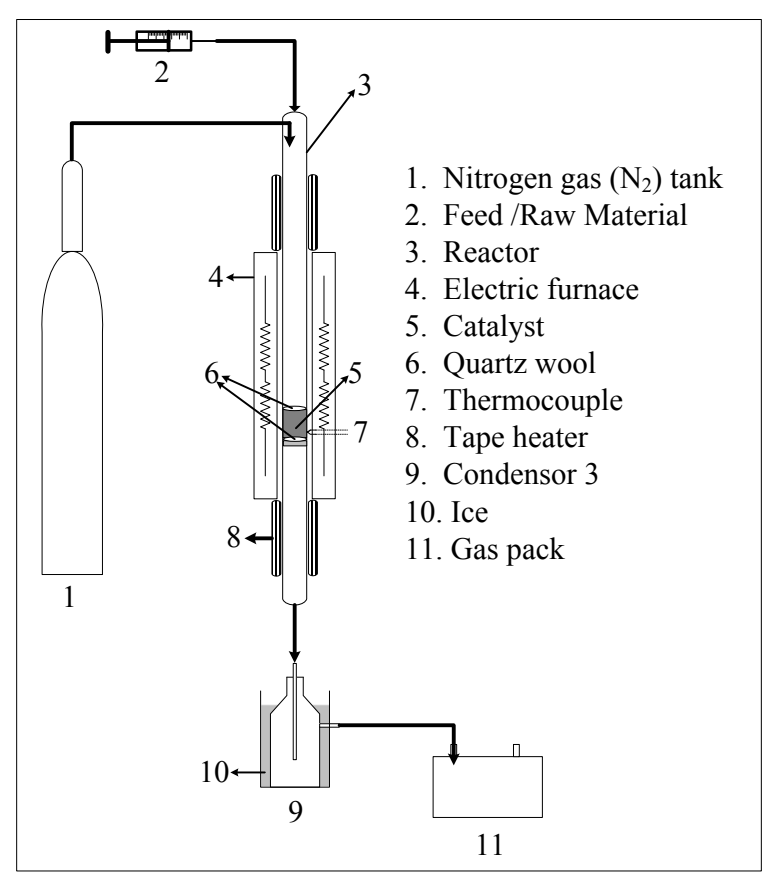

Figure 4. A schematic diagram of catalytic reaction of pyroligneous acid apparatus

The liquid product was analyzed by GCMS (Agilent Technologies 5977A
MSD) using DB-Wax column. The calculation of product composition was based on peak area of GC-MS. The n-butanol was added to the sample as the internal standard. The calculation based on peak area of GC-MS. Area of the component was compared with the n-butanol area to calculate mol and carbon mol (C-mol) of the component based on mol and C-mol of n-butanol. C-mol of the component was divided by $\mathrm{C}$-mol of pyroligneous acid and then multiplied by $100 \%$ to find $\mathrm{C}-\mathrm{mol} \%$ of group chemicals. C-mol of pyroligneous acid was calculated according to its carbon content of elemental analysis.

$\mathrm{C}-\mathrm{mol} \%$ of component in the product was subtracted by $\mathrm{C}-\mathrm{mol} \%$ of component in pyroligneous acid to get the changes of yield for each group of chemicals (C-mol\%).

The amount of coke-like residue deposited on the catalyst was measured by an elemental analyzer (Leco CHN 682). Product yields of the catalytic reaction were calculated based on the carbon contents of feed (pyroligneous acid).

\section{RESULTS AND DISCUSSION Chemical Composition of Pyroligneous Acid}

During pyrolysis, there are several chemical reactions occurred and produced solid, water vapor, tar, volatiles, and gaseous products (Mansur et al. 2013). Water vapor, tar, and volatiles were condensed using three stages condensers with the same temperature of $0{ }^{\circ} \mathrm{C}$. The uncondensable vapor and gaseous products were trapped in the water trap before released to the environment.

The pyrolysis oil was separated into the oil phase and the pyroligneous acid. The pyroligneous acid was mainly derived from pyrolysis of cellulose and hemicellu- 
lose in PKS (Mansur et al. 2013). In this study, the pyroligneous acid, which was an organic-containing water solution, used as the feedstock for the catalytic reaction. Based on data from GCMS analysis, the chemical compounds in the pyroligneous acid were grouped into aliphatic ketones, cyclic ketones, furans, heterocyclic organic compounds, carboxylic acids, phenols, and benzenediols. The yields of chemical composition are shown in Table 1.

Table 1. The chemical composition of pyroligneous acid

\begin{tabular}{cc}
\hline Components & $\begin{array}{c}\text { Composition } \\
{[\text { C mol\%] }}\end{array}$ \\
\hline Aliphatic ketones & 2.38 \\
Cyclic ketones & 3.50 \\
Furans & 6.78 \\
Heterocyclic organic compounds & 1.32 \\
Carboxylic acids & 38.24 \\
Phenols & 43.50 \\
Benzenediols & 2.77 \\
Others & 1.51 \\
\hline
\end{tabular}

\section{Characterization of Iron Ores Catalyst}

In an application of iron ores as a natural mineral product for catalyst in the catalytic reaction of the pyroligneous acid, some analysis were needed such as TGA, XRD, SEM, and EDX. Thermal Gravimetric Analysis (TGA) and Differential Thermogravimetric (DTG) curves were needed in the selection of thermal treatment of the iron ores for catalyst purpose. The TGA and DTG curves of the iron ore are shown in Figure 5.

According to Figure 5, thermal degradation of iron ore took place within a wide range from 150 to $550{ }^{\circ} \mathrm{C}$ which consisted of two distinct decomposition regions: $150-400{ }^{\circ} \mathrm{C}$ and $400-550{ }^{\circ} \mathrm{C}$. Around temperatures of $600-700{ }^{\circ} \mathrm{C}$, there were peaks that correspond to change in carrier gas from nitrogen to oxygen during analysis. In decomposition region of 150 $400{ }^{\circ} \mathrm{C}$, it was predicted that moisture

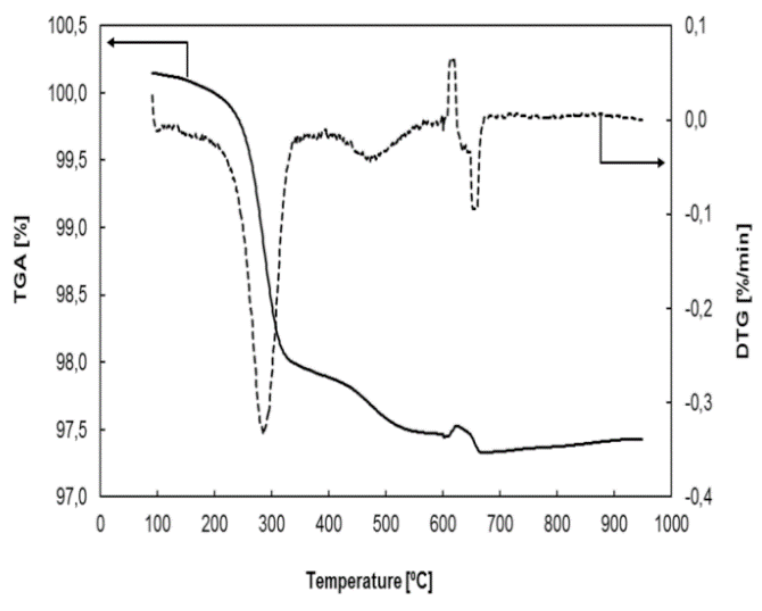

Figure 5. TGA and DTG curves of iron ore

content of iron ores was vaporized. This prediction was confirmed by XRD analysis using two samples of iron ores that heated at $200{ }^{\circ} \mathrm{C}$ and $400{ }^{\circ} \mathrm{C}$ that represent prior to and after the decomposition region. XRD patterns of the iron ores can be seen in Figure 6.

Based on Figure 6, XRD patterns of both of the iron ores were the same that peaks of $\mathrm{Fe}_{2} \mathrm{O}_{3}$ and $\mathrm{SiO}_{2}$ appeared in the same position. Therefore, by heating treatment at $200{ }^{\circ} \mathrm{C}$ and $400{ }^{\circ} \mathrm{C}$, there were changes in crystallography of the iron ores. Referred to XRD analysis, it was found that crystal system of $\mathrm{Fe}_{2} \mathrm{O}_{3}$ was rhombohedral and $\mathrm{SiO}_{2}$ was hexagonal with their

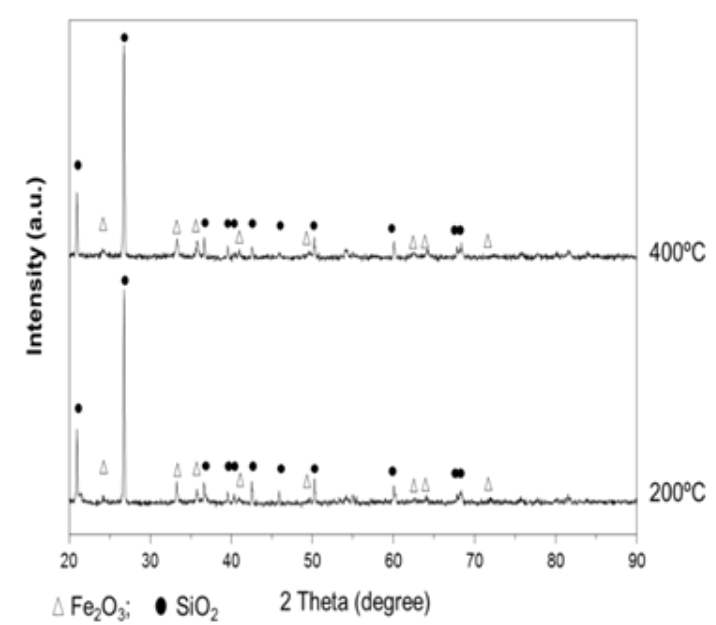

Figure 6. XRD analysis of iron ore after heating at $200{ }^{\circ} \mathrm{C}$ and $400{ }^{\circ} \mathrm{C}$ 
fraction volume were $48.4 \%$ and $51.6 \%$, respectively.

Moreover, the iron ores were also analyzed by SEM + EDX to show their microstructure and composition of elements and the results are shown in Figure 7. The microstructure of the iron ores was not uniform and maximum around $20 \mu \mathrm{m}$. In EDX analysis, three representing spectrums were analyzed to give the atomic ratio for each element and the atomic ratios for each element were different. According to the atomic ratio, the spectrum 1 and spectrum 2 can be considered as $\mathrm{SiO}_{2}$ and $\mathrm{Fe}_{2} \mathrm{O}_{3}$, respectively. On the other hands, spectrum 3 consisted of a mixture of oxides $\left(\mathrm{Al}_{2} \mathrm{O}_{3}\right.$, $\mathrm{SiO}_{2}$, and $\mathrm{Fe}_{2} \mathrm{O}_{3}$ ). Therefore, the iron ores were not only iron oxide $\left(\mathrm{Fe}_{2} \mathrm{O}_{3}\right)$ but also containing other oxides.

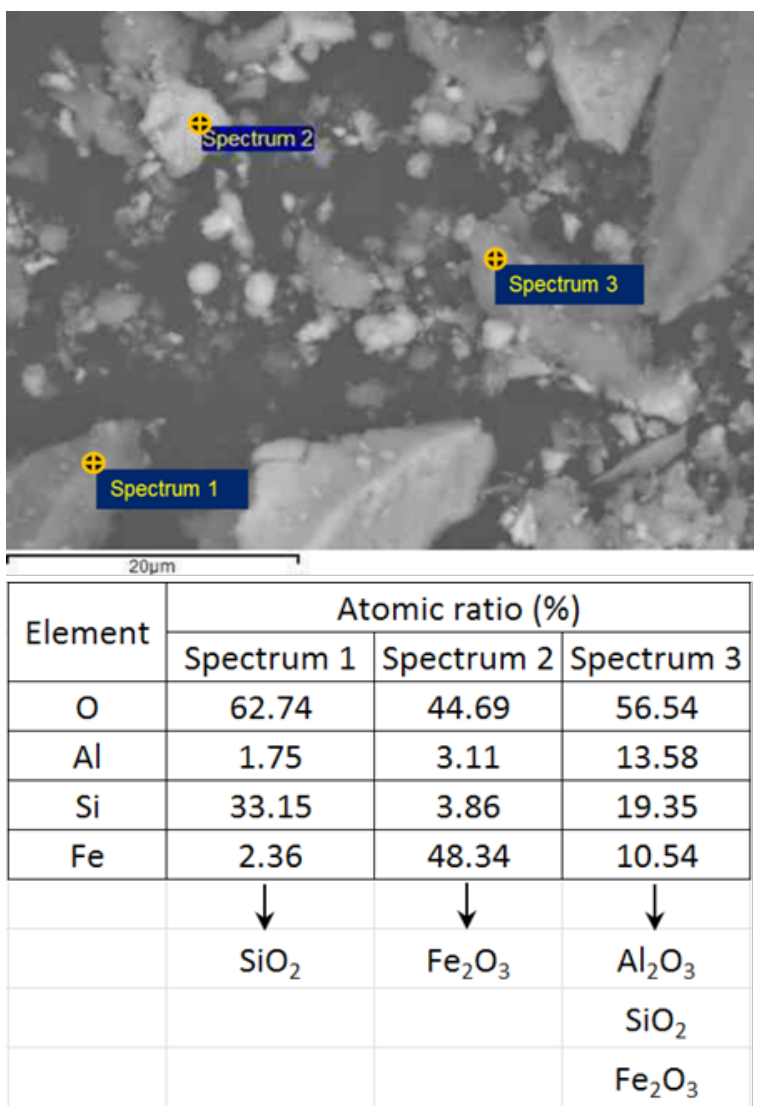

Figure 7. SEM and EDX analysis of iron ore

Before used as a catalyst, the iron ores were treated in several ways as shown in
Figure 1. The treatments were aimed to increase the surface area of the ore prior to use as the catalyst. The catalyst was analyzed using surface area analyzer (Micromeritic tristar II) to identify BET surface area. The BET surface area of the catalyst is shown in Table 2.

Table 2. Catalyst surface area

\begin{tabular}{cc}
\hline Catalyst & $\begin{array}{c}\text { BET Surface Area } \\
\left(\mathrm{m}^{2} \mathrm{~g}^{-1}\right)\end{array}$ \\
\hline Catalyst no. 1 & 3.78 \\
Catalyst no. 2 & 18.77 \\
Catalyst no. 3 & 19.90 \\
Catalyst no. 4 & 19.33 \\
Catalyst no. 5 & 11.33 \\
\hline
\end{tabular}

According to Table 2, iron ores after calcination at $500{ }^{\circ} \mathrm{C}$ (catalyst no. 3) had a higher BET surface area than others. It was suggested that calcination at $500{ }^{\circ} \mathrm{C}$ allowed volatile which trapped between molecules to evaporate. It caused empty pores between the iron ore's molecules lead to increase the surface area of the catalyst.

\section{Catalytic Reaction of Pyroligneous Acid over Natural Iron Ores Catalyst}

Catalytic reaction of pyroligneous acid was conducted to investigate the activity of natural iron ores as the catalyst for ketonization reaction. Five types of the catalysts as listed in Figure 1 or Table 2 were used for the catalytic reaction of two concentrations of pyroligneous acid; the pyroligneous acid used as produced and $50 \%$ diluted in distilled water, hereafter called as $100 \%$ feed and $50 \%$ feed of pyroligneous acid, respectively.

The yield of the catalytic reaction of $50 \%$ feed of pyroligneous acid over natural iron ores catalyst is shown in Figure 8. Moreover, the changes of yield for each 
group of chemicals compared to feed are shown in Table 3.

According to Figure 8 and Table 3, ketonization reaction occurred over natural iron ores catalysts because the yield of aliphatic ketones increased while carboxylic acid decreased.

Table 3. The changes of yield for each group of chemicals over natural iron ores catalyst using $50 \%$ feed of pyroligneous acid

\begin{tabular}{|c|c|c|c|c|c|c|}
\hline $\begin{array}{l}\text { Group of } \\
\text { Chemicals }\end{array}$ & I & $\begin{array}{l}\text { Chang } \\
--- \\
1\end{array}$ & $\begin{array}{l}-\overline{\text { of Che }} \\
---\end{array}$ & $\begin{array}{l}\text { hicals } 0 \\
- \text { mol } \% \\
3\end{array}$ & ir the C & alyst \\
\hline Aliphatic ketones & $i$ & 0.80 & 1.88 & 0.64 & 0.39 & 0.12 \\
\hline Cyclic ketones & $\begin{array}{l}1 \\
1\end{array}$ & 4.18 & 3.54 & 0.88 & -0.96 & 0.75 \\
\hline Furans & $\begin{array}{l}1 \\
1\end{array}$ & -0.12 & -0.17 & -1.49 & -0.66 & -0.22 \\
\hline $\begin{array}{l}\text { Heterocyclic organic } \\
\text { compound }\end{array}$ & $\begin{array}{l}1 \\
1 \\
1\end{array}$ & 1.17 & 0.80 & -0.25 & -0.70 & -0.40 \\
\hline Carboxylic acids & $\begin{array}{l}1 \\
1\end{array}$ & -2.69 & -3.32 & -1.89 & -0.25 & -0.02 \\
\hline Phenols & $\begin{array}{l}1 \\
1 \\
1\end{array}$ & -7.75 & -7.09 & 0.26 & 0.99 & -2.05 \\
\hline Benzenediols & $\begin{array}{l}1 \\
1\end{array}$ & 3.52 & 2.38 & 1.22 & -0.51 & 0.87 \\
\hline Others & $\begin{array}{l}1 \\
1\end{array}$ & -0.53 & -1.33 & -1.21 & -1.46 & -1.34 \\
\hline
\end{tabular}

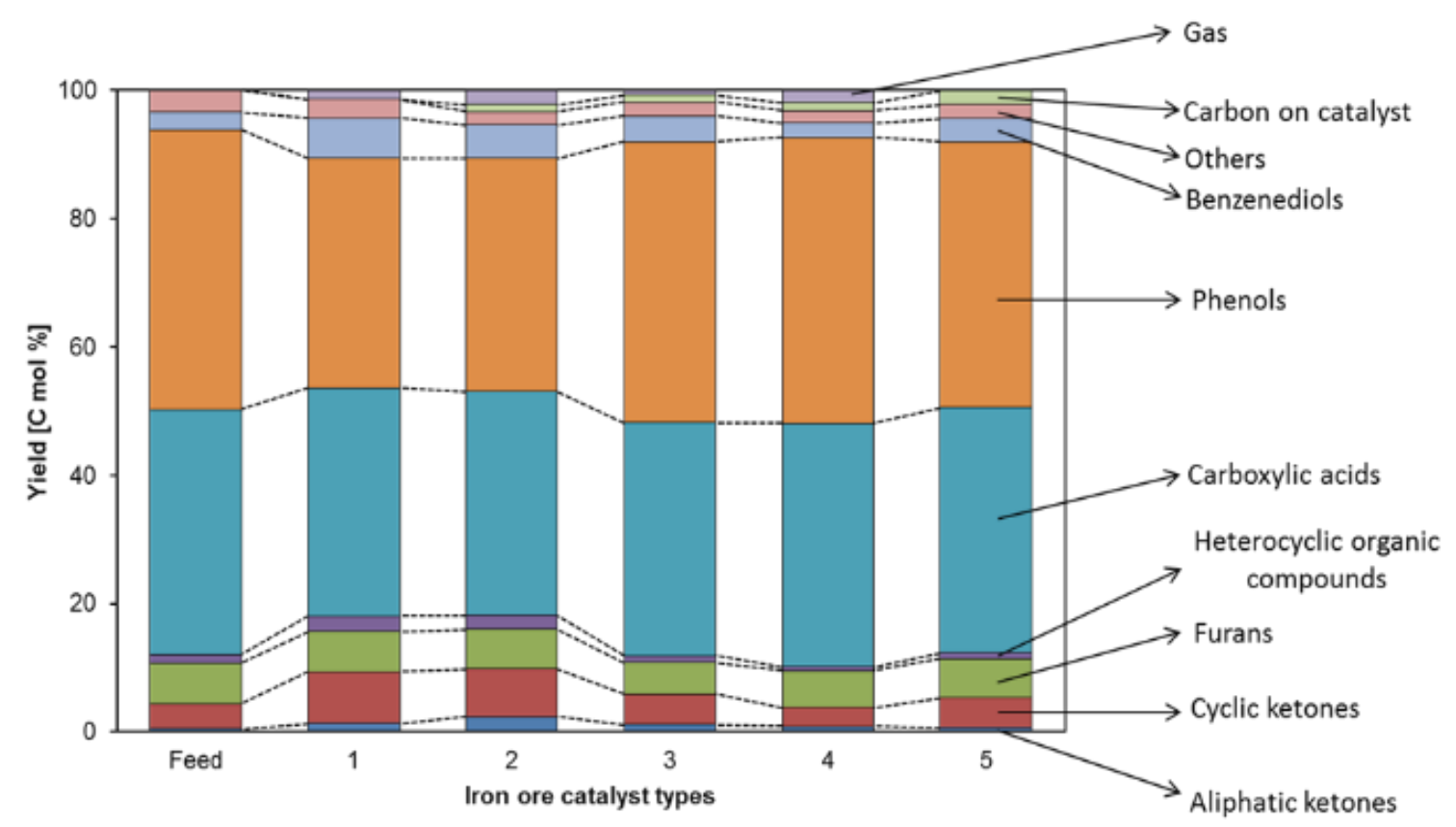

Figure 8. Yield of 50\% w/w pyroligneous acid catalytic reaction process result 
As it is explained before that ketonization is a reaction of two molecules of carboxylic acids to form a molecule of aliphatic ketones and a molecule of $\mathrm{CO}_{2}$ (Mansur et al. 2013). The increase in yield of aliphatic ketones was higher over iron ores catalyst calcinated at $285^{\circ} \mathrm{C}$ (catalyst no. 2) than other catalysts. In point of view of ketonization reaction, natural iron ores that can be used as catalyst and calcination at $285^{\circ} \mathrm{C}$ was good enough for the catalyst treatment although BET surface area of catalyst calcined at $500{ }^{\circ} \mathrm{C}$ for two hours (catalyst no. 3) and steam treatment at 500 ${ }^{\circ} \mathrm{C}$ for 1 hour (catalyst no. 4) were higher than catalyst no 2. Catalyst no. 2 can increase the yield of aliphatic ketones as $2 \mathrm{C}-\mathrm{mol} \%$ based on feed. The increasing yield was low compared to $\mathrm{ZrO}_{2}-\mathrm{FeO}_{\mathrm{x}}$ catalyst that reached about $26 \mathrm{C}-\mathrm{mol} \%$.
It was predicted that the increase of aliphatic ketones yields over catalyst no. 2 will be higher if operated in W/F of 4 as well as the $\mathrm{ZrO}_{2}-\mathrm{FeO}_{\mathrm{x}}$ catalyst.

Figure 8 and Table 3 were also shown the yield of phenols and benzenediols. Some of the phenols decreased followed by increasing benzenediols. It was caused by oxidation of phenols to form benzenediols (Greenhill-hooper et al. 2008).

Moreover, some of the phenols yields also increased that caused by the reaction of guaiacol via benzenediols (Amen-chen et al. 2001).

The yield of the catalytic reaction of $100 \%$ feed of pyroligneous acid over natural iron ores catalyst is shown in Figure 9 and the changes of the yield that calculated based on chemicals in the feed are shown in Table 4.

Table 4. The changes of yield for each group of chemicals over natural iron ores catalyst using $100 \%$ feed of pyroligneous acid

\begin{tabular}{|c|c|c|c|c|c|c|}
\hline $\begin{array}{c}\text { Group of } \\
\text { Chemicals }\end{array}$ & I & $\begin{array}{c}\text { Chang } \\
--- \\
1\end{array}$ & $\begin{array}{c}\text { of Cher } \\
--\frac{1}{2}\end{array}$ & $\begin{array}{l}\text { cals Ov } \\
\text { nol } \frac{\%}{3} \\
3\end{array}$ & the $\mathrm{Ca}$ & $\begin{array}{l}\text { lyst } \\
5\end{array}$ \\
\hline Aliphatic ketones & I & 0.54 & -1.38 & -0.93 & -1.64 & -1.41 \\
\hline Cyclic ketones & $\begin{array}{l}\text { I } \\
\text { I }\end{array}$ & 3.06 & 0.17 & 0.31 & 0.35 & 1.35 \\
\hline Furans & $\begin{array}{l}\mathbf{1} \\
\mathbf{1}\end{array}$ & 1.84 & -1.12 & -0.97 & 1.13 & 1.02 \\
\hline $\begin{array}{l}\text { Heterocyclic organic } \\
\text { compounds }\end{array}$ & $\begin{array}{l}\text { I } \\
\text { I } \\
\text { I }\end{array}$ & 0.78 & -0.33 & -0.90 & -0.50 & $=0.53$ \\
\hline Carboxylic acids & $\begin{array}{l}1 \\
1\end{array}$ & -8.61 & -0.31 & 2.48 & -1.70 & -3.03 \\
\hline Phenols & $\begin{array}{l}\text { I } \\
\text { I }\end{array}$ & -10.38 & -0.72 & -2.46 & -2.91 & -3.91 \\
\hline Benzenediols & $\begin{array}{l}\text { I } \\
\text { I } \\
\text { I }\end{array}$ & 2.02 & -0.32 & -1.62 & 1.08 & 1.59 \\
\hline Others & i & 2.94 & -1.24 & -0.66 & 0.00 & 0.76 \\
\hline
\end{tabular}

Positive values mean increase in yield

Negative values mean decrease in yield 


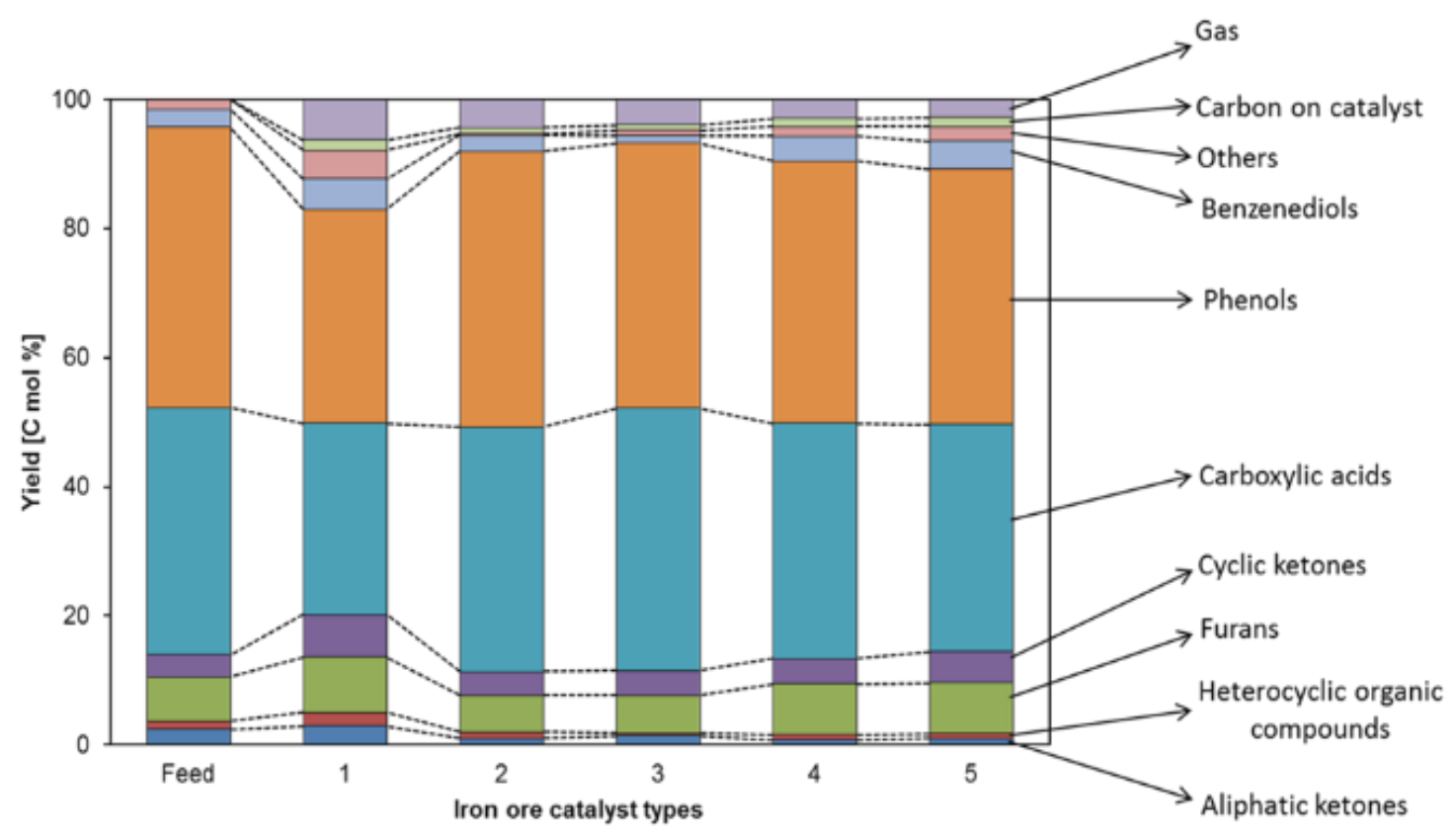

Figure 9. Yield of $100 \% \mathrm{w} / \mathrm{w}$ feed of pyroligneous acid catalytic reaction process result

According to Figure 9 and Table 4, ketonization reaction only occurred over fresh natural iron ores catalyst (catalyst no. 1) because of the increase of aliphatic ketones and the decrease of carboxylic acids. While catalytic reactions of $100 \%$ feed of pyroligneous acid over catalyst no. 2 to 5 were shown a decrease in yield of aliphatic ketones. It was caused by the high concentration of feed and low selectivity of the catalyst for ketonization reaction. Therefore, the formation of gas as decomposition of pyroligneous acid was high at high temperature.

Over catalyst no.1 (natural iron ore) oxidation of phenols into benzenediols also occurred because of the decrease of phenol yield as well as increasing benzenediols yield. It was suggested that $100 \%$ feed of pyroligneous acid was not so suitable for investigation activity of natural iron ores catalyst in ketonization reaction.

\section{CONCLUSIONS}

After some treatments, iron ores can be used as a catalyst for ketonization reaction. Iron ores contain not only iron oxide $\left(\mathrm{Fe}_{2} \mathrm{O}_{3}\right)$ but also other oxides such as $\mathrm{SiO}_{2}$ and $\mathrm{Al}_{2} \mathrm{O}_{3}$. The iron ores which calcined at $285^{\circ} \mathrm{C}$ showed a higher activity than other catalysts in this study.

It can increase the yield of aliphatic ketones by about $2 \mathrm{C}-\mathrm{mol} \%$ during the catalytic reaction with $50 \%$ feed of pyroligneous acid as the raw material. In this case, neither calcination up to $500{ }^{\circ} \mathrm{C}$ nor steam treatment can increase the activity of natural iron ores as the catalyst for ketonization reaction even though the BET surface area increased.

\section{ACKNOWLEDGEMENTS}

This work was supported by Research Center for Chemistry, Indonesian Institute of Sciences. We acknowledge Ir. M. Yunus, 
MTA form Research Unit for Mineral Technology in Lampung for sending us the natural iron ore.

\section{REFERENCES}

Amen-chen, Carlos, Hooshang Pakdel, and Christian Roy. 2001. "Production of Monomeric Phenols by Thermochemical Conversion of Biomass : A Review." Biore 79: 277-99.

BÖRJESSON, P.I.I. 1996. "Emissions of $\mathrm{CO} 2$ from Biomass Production and Transportation in Agriculture and Forestry." Energy Conversion and Management 37 (95): 1235-40.

Bridgwater, A V. 2011. "Review of Fast Pyrolysis of Biomass and Product Upgrading." Biomass and Bioenergy 38.ElsevierLtd:68-94.doi:10.1016/j. biombioe.2011.01.048.

Das, Debabrata, and T Nejat Veziroä. 2001. "Hydrogen Production by Biological Processes: A Survey of Literature." International Journal of Hydrogen Energy 26: 13-28.

Demirbas, Ayhan, and Gönenç Arin. 2001. "An Overview of Biomass Pyrolysis." Energy Source 24: 471-82.

Dincer, Ibrahim. 2011. "Green Methods for Hydrogen Production." International Journal of Hydrogen Energy 37 (2). Elsevier Ltd: 1954-71. doi:10.1016/j. ijhydene.2011.03.173.

Elliott, Douglas C, Patrick Biller, Andrew B Ross, Andrew J Schmidt, and Susanne B Jones. 2015. "Bioresource Technology Hydrothermal Liquefaction of Biomass: Developments from Batch to Continuous Process." Bioresource Technology 178. E1sevier Ltd: 147-56. doi:10.1016/j. biortech.2014.09.132.

Fumoto, Eri, Yosuke Mizutani, Teruoki Tago, and Takao Masuda. 2006. "Production of Ketones from Sewage Sludge over Zirconia-Supporting
Iron Oxide Catalysts in a Steam Atmosphere." Applied Catalysis B: Environmental 68: 154-59. doi:10.1016/j.apcatb.2006.08.006.

Greenhill-hooper, Michael John, Robert Raja, and John Meurig-Thomas. 2008. "Selective Oxidation of Organic Compounds." united states. http://patentimages.storage.googleapis.com/pdfs/US20080227984.pdf.

Hyman, D, A Sluiter, D Crocker, D Johnson, J Sluiter, S Black, and C Scarlata Nrel. 2008. Determination of Acid Soluble Lignin Concentration Curve by UV-Vis Spectroscopy. National Renewable Energy Laboratory.

Kalinci, Yildiz, Arif Hepbasli, and Ibrahim Dincer. 2009. "Biomass-Based Hydrogen Production: A Review and Analysis." International Journal of Hydrogen Energy 34 (21). Elsevier Ltd: $\quad 8799-8817$. doi:10.1016/j. ijhydene.2009.08.078.

LeValley, Trevor L, Anthony R Richard, and Maohong Fan. 2014. "The Progress in Water Gas Shift and Steam Reforming Hydrogen Production Technologies - A Review." International Journal of Hydrogen Energy 39 (30). Elsevier Ltd: 16983-0. doi:10.1016/j.ijhydene.2014.08.041.

Loo, A Y, K Jain, and I Darah. 2007. "Food Chemistry Antioxidant and Radical Scavenging Activities of the Pyroligneous Acid from a Mangrove Plant, Rhizophora Apiculata" 104: 300-307. d o i : 10 . $1016 / \mathrm{j}$. f o o d chem.2006.11.048.

Mansur, Dieni, Teruoki Tago, Takao Masuda, and Haznan Abimanyu. 2014. "Conversion of Cacao Pod Husks by Pyrolysis and Catalytic Reaction to Produce Useful Chemicals." Biomass and Bioenergy 66. Elsevier Ltd: 275-85. d o i : $10.1016 /$ j.b i o m b i oe.2014.03.065. 
Mansur, Dieni, Takuya Yoshikawa, Koyo Norinaga, Jun-ichiro Hayashi, and Teruoki Tago. 2013. "Production of Ketones from Pyroligneous Acid of Woody Biomass Pyrolysis over an Iron-Oxide Catalyst." Fuel 103. Elsevier Ltd: 130-34. doi:10.1016/j. fuel.2011.04.003.

Mathew, Sindhu, Zainul Akmar Zakaria, and Nur Fashya Musa. 2015. "Antioxidant Property and Chemical Profile of Pyroligneous Acid from Pineapple Plant Waste Biomass." Process Biochemistry 50 (11). Elsevier Ltd: 1985-92. doi:10.1016/j. procbio.2015.07.007.

Möbius, Anja, Nikolaos Boukis, Ulrich Galla, and Eckhard Dinjus. 2012. "Gasification of Pyroligneous Acid in Supercritical Water" 94: 395-400. doi:10.1016/j.fuel.2011.11.023.

Molino, Antonio, Simeone Chianese, and Dino Musmarra. 2016. "Biomass Gasification Technology: The State of the Art Overview." Journal of Energy Chemistry 25 (1). Elsevier B.V.: 10-25. doi:10.1016/j. jechem.2015.11.005.

Sembiring, Kiky C, Nino Rinaldi, and Sabar P Simanungkalit. 2015. "Bio Oil from Fast Pyrolysis of Empty Fruit Bunch at Various Temperature." Energy Procedia 65. Elsevier B.V.: 162-69. doi:10.1016/j. egypro.2015.01.052.

Shweta, Sharma, and Pratik N Sheth. 2016. "Air - Steam Biomass Gasification: Experiments, Modeling and Simulation." Energy Conversion and Management 110 . Elsevier Ltd: 307-18. doi:10.1016/j.enconman.2015.12.030.

Sjaak van, Loo, and Koppejan Jaap, eds. 2008. The Handbook of Biomass Combustion \& Co-Firing. Earthscan.

Sluiter, A, B Hames, R Ruiz, C Scarlata, J Sluiter, and D Templeton. 2008. Determination of Ash in Biomass.
Sluiter, A, D Hyman, C Payne, and J Wolfe. 2008. Determination of Insoluble Solids in Pretreated Biomass Material.

Sluiter, A, and J Sluiter. 2008. Determination of Starch in Solid Biomass Samples by HPLC.

Sumanatrakul, Panita, Panita Kongsune, Lakana Chotitham, and Unwena Sukto. 2015. Utilization of Dendrocalamus Asper Backer Bamboo Charcoal and Pyroligneous Acid. Energy Procedia. Vol. 79. Elsevier B.V. doi:10.1016/j.egypro.2015.11.558.

Wei, Qin, Xihan Ma, Zhong Zhao, Shanshan Zhang, and Shengchen Liu. 2010. "Journal of Analytical and Applied Pyrolysis Antioxidant Activities and Chemical Profiles of Pyroligneous Acids from Walnut." Journal of Analytical and Applied Pyrolysis 88 (2). Elsevier B.V.: 149-54. doi:10.1016/j.jaap.2010.03.008.

Zhang, Qi, Jie Chang, Tiejun Wang, and Ying $\mathrm{Xu}$. 2006. "Upgrading BioOil over Different Solid Catalysts." Energy \& Fuels 20 (9): 2717-20.

Zhang, Xiaodong, Laizhi Sun, Lei Chen, Xinping Xie, Baofeng Zhao, Hongyu $\mathrm{Si}$, and Meng Guangfan. 2014. "Comparison of Catalytic Upgrading ofBiomass Fast Pyrolysis Vapors over $\mathrm{CaO}$ and $\mathrm{Fe}$ (III)/ CaO Catalysts." Journal of Analytical and Applied Pyrolysis 108. Elsevier B.V.: 35-40. doi:10.1016/j.jaap.2014.05.020. 